\title{
Work-Life Balance and Job Satisfaction: An Empirical study Focusing on Higher Education Teachers in Oman
}

\author{
K. Agha, F. T. Azmi, and A. Irfan
}

\begin{abstract}
With increasing levels of stress, competition and insecurities in life, work-life balance issues have become extremely important. Employees are looking for ways that will help them balance between work and personal life effectively. Researchers have also identified that work-life balance leads to positive organizational outcomes.

Although work-life balance has been a frequent subject of inquiry in the Western world, there have been no studies on work-life balance in the Sultanate of Oman. Human resources are being considered as vital for the realization of the 'Vision for Oman's National Economy: Oman 2020' laid by the Sultanate, and hence, a study on work-life balance is both timely and relevant. It needs to be understood that teachers are the cornerstone of the development of any society and hence their well-being is important. Therefore, the present study seeks to explore work-life balance and its relation to job satisfaction of teachers in the higher education sector in the Sultanate of Oman.

Findings of the study revealed that while work interference with personal life and personal life interference with work had a negative relationship with job satisfaction, work and personal life enhancement had a positive relationship with job satisfaction. Thus, the findings of the present study corroborate with previous research evidence. Thus, we can safely conclude that work and personal life needs to be integrated and balanced by organizations through work-life balance initiatives.
\end{abstract}

Index Terms-Work-life balance, job satisfaction, teacher satisfaction, sultanate of Oman, higher education.

\section{INTRODUCTION}

Work-life balance (WLB) is about finding the right balance between work and life, and about feeling comfortable with both work and family commitments. Work-life balance is essentially the balance between three components, namely, paid work, unpaid work and personal time. There is no one accepted definition of what constitutes a WLB practice, the term usually refers to one of the following factors: organizational support for dependent care, flexible work options and family or personal leave [1].

Reference [2] describes WLB as juggling of five aspects of one's life at any one point in time, namely, work, family, friends, health and self. Reference [3] defined WLB as awareness of different demands in relation to energy and time, ability to allocate the time and energy among different

Manuscript received April 25, 2016; revised June 28, 2016.

K. Agha is with Skyline University College, Sharjah, United Arab Emirates (e-mail: kakul_p@yahoo.com).

F T. Azmi is with Aligarh Muslim University, Aligarh, India (e-mail: ftazmi@gmail.com).

A. Irfan is a PhD scholar with Aligarh Muslim University, Aligarh, India (e-mail: adeeba09@gmail.com). domains of work and life and then to apply and make choices. WLB includes practices that have the capacity to increase the autonomy and flexibility of employees in the process of balancing different requirements. Some WLB issues are extremely important in the workplace, like increased level of stress, competition and insecurities in the workplace. All these factors are key and lead to disruption in WLB [4].

Changes in the workplace and in employee demographics in the past decade have led to an increased concern for the boundary between employee work and non-work lives. Issues related to scheduling and reaching work may also create uncertainty. Job requirements, such as mandatory overtime, shift work, on-call requirements, and evening / weekend / holiday coverage often impose on employees' personal time [5].

In this regard, interference between work and non-work responsibilities has a number of negative outcomes. In terms of job attitudes, employees reporting high levels of both work-to-life and life-to-work conflict tend to exhibit lower levels of job satisfaction and organizational commitment [6], [7]. Both work-to-life and life-to-work conflict have also been associated with increased stress and burnout [8], [9], cognitive difficulties such as staying awake, lack of concentration, and low alertness [10], as well as reduced levels of general health and energy [11].

WLB can be used as a key component in any organization as an employee retention strategy [12]. It has been found that if organizations want to retain their employees then they should have appropriate work-life balance policies. Reference [13] found that owing to increased work-life imbalance, the rate of long-term sick leave was increasing in Sweden rapidly. This is the reason for why those who are in the education and human service sectors are more prone to ill-health with the pressure to increase productivity, especially women who are middle-aged [13].

Work-life balance is important for life, family and job satisfaction and it also helps in reducing absenteeism and employee turnover [14]. WLB policies also affect the well-being of employees and may include [15]:

- Having flexi-time options

- Instituting job sharing

- Working from home

- Having parental paid leave

- Having a nursery in work place

It has been shown that non-standard hours of work have a negative bearing on WLB, and if an employee works 46 hours or more in a week then that employee will often be dissatisfied and stressed. Reference [16] identified that an employee has to work 1900 hours per year, which is based on the number of working hours / week minus holidays. Working beyond this time, leads to work-life imbalance. 
Compressed working weeks or compressed hours of work can help an employee work fewer days to achieve their targets and then they can manage their family responsibilities during the remaining days [16]. Flexi- time also has a positive impact on productivity [17]. In the same way, flexi-time enables women employees achieve greater balance between family and work roles [18].

The nature of the job, workplace environment, employee-friendly policies and organizational culture have a positive impact on WLB [19]. All employee-friendly policies that are beneficial to employees, increase job satisfaction and organizational commitment. In addition to this, [20] examined that family-responsive policies, flexible-work schedule and dependent care, as part of WLB policies, have had a positive impact on turnover intentions and organizational commitment. As a result, adopting a strategic WLB framework at the firm level, is pertinent [21].

Reference [22] suggested that WLB practices depend on attracting better applicants and reducing work-life conflict, hence, it enhances organizational performance. Reference [23] found that WLB policies and practices reap benefits to the organization that can be measured financially, namely, increased productivity, lower absenteeism, reduced overheads, improved recruitment and retention.

Job satisfaction is how people feel about their job. It depends on the extent to which people are satisfied or dissatisfied with their job. Reference [24] identified that job satisfaction is an important predictor of overall well-being and employee intentions to quit. As a result, there is a relationship between job satisfaction and employee retention [25]. Reference [26] too concluded that job satisfaction is a positive outcome of WLB. Reference [27] suggested that when an employee perceives that his/her employer is supportive and is helpful in integrating family and work related issues, it results in a higher level of job satisfaction and organization commitment. Reference [28] determined that there is impact of work obligations on personal life and that there is a link or relationship between the WLB and job satisfaction. Reference [29] found that if there is fairness in policies, then the workers are likely to be more satisfied.

\section{CONCEPT OF WORK-LIFE BALANCE}

Reference [30] explores the interface between work and family at different types of institutions from the perspective of women faculty who are on the tenure track and who are mothers of young children. Such a perspective provides insight into institutional variation on academic life in general, and for new faculty as mothers, in particular. A macro-view of the findings points to two major concerns, namely, time (and lack thereof) and its impact on the ideal worker norms that shape what it means to be a good mother and good professor at different institutional types, as well as, the idea of 'choice' as an illusion.

Reference [31] found that making use of at least one work-family policy helped academic mothers increase their productivity (without increasing their hours of work). But it also appears that this help is not treated as a needs-based entitlement.

For Reference [32], the presence of work-related stress and strain is viewed as a serious concern for faculty, particularly, newer and female faculty. It examined differences in levels of occupational stress and personal strain experienced by new and experienced female and male faculty. Results on the negative impact of role overload and avoiding coping on measures of personal strain are consistent with the literature and suggest the need for promoting different coping strategies in the academic workplace as well as working with faculty to help them prioritize and balance their daily workloads [32].

Reference [33] found that retention of female faculty is an important issue for higher education institutions aiming for excellence and diversity. The first step in understanding retention is to examine what contributes to career satisfaction for academic women. Using the reference [34] model for conceptualizing faculty job satisfaction, the study identifies domains of environmental condition, departmental climate and demographics play a role in female faculty's overall career satisfaction.

The Sultanate of Oman has a long-standing policy of human resource development through education and training, although the Omani higher education system is relatively young and is in its juvenile stages of development. The government is taking steady strides to enhance the quality, pervasiveness and robustness of the education system in the Sultanate. Although, a large number of studies are available on the growth and development of the higher education system, minimal research has been found on the human resource management issues related to teachers.

Reference [35] studied job satisfaction and organizational citizenship behavior both from private as well public sectors in Oman. Another study [36] concluded that certain demographic variables such as age, tenure have bearing on job satisfaction and organization commitment. Reference [37] conducted a study in Oman to test job satisfaction among school teachers of Oman, and in the school, turnover problems were checked.

However, the researchers did not find any studies on work-life balance in Oman that focused specifically on the higher education sector. They have identified that higher education and training and development are the key to success. Human resource development is at the heart of the major strategies considered critical to the realization of the 'Vision for Oman's National Economy: Oman 2020', which is the vision laid by the Sultanate [38].

\section{StUdy OBJEctives}

In light of the research gaps, the following objectives were identified

- To measure work-life balance, teaching and job satisfaction of teachers in the higher education institutions in the Sultanate of Oman

- To explore the relationship between work-life balance, teaching satisfaction and job satisfaction

\section{RESEARCH CONSTRUCTS}

Reference [39] explained why WLB is significant and how the stressful events of life have an impact on work-life 
balance. Reference [40] developed an instrument in the form of a WLB checklist. Reference [41] presented significant insights into the troubles of combining family aspirations with salaried work in relation to policy relevant agendas with the help of a social survey.

Reference [42] investigate the role of time diaries in the study of WLB; which consider three sets of WLB measures: 1) proportion of free time, 2) overlap of work and life, and 3) time spent with other people. Reference [43] reviewed methodological choices (sampling frames, measures used and constructs investigated) in 245 empirical work-life balance papers published between 1987 and 2006. Results showed that WLB studies require setting-up better reliability between the conceptualization of constructs and the operationalization of measures.

Reference [44] defined work-home interaction by developing four types of work-home interaction. The questionnaire measured four different types of work-home interaction, and this four-dimensional configuration was largely invariant across the five samples as well as across relevant subgroups. Reference [45] developed a theoretical framework that explained how life complexity and dynamism affect work-life balance which were taken as independent variable and WLB as dependent variable. Reference [46] carried out the psychometric assessment of an instrument designed to measure work-life balance. The purpose of study was to evaluate a 15 item scale for assessing the construct of WLB with the intention to find the balance between life-to-work and work-to-life. For the present study, WLB constructs have been adopted from the study of [46].

\section{A. Independent Variable: Dimensions of WLB}

Work Interference with Personal Life (WIPL): According to [46], WIPL includes those work-related factors that impact the personal life of individuals. This construct tries to measure the impact of work on the personal life of individuals. It consist of items like: My personal life suffers because of work, I put personal life on hold for work.

Personal Life Interference with Work (PLIW): Reference [46] explains PLIW as the impact of or the interference of personal life on work. This construct aims at measuring the reverse phenomenon, namely, the impact of personal life on the work of individuals. There were four items to measure this construct like: I am too tired to be effective at work.

Work Personal Life Enhancement (WPLE): WPLE explains how both work and personal life enhance and support each other. The items listed in this construct help to understand the support and enhancement provided by work on personal life and vice versa. This was measured using four items, for example, my job gives me energy to pursue personal activities.

\section{B. Dependent Variable: Job Satisfaction (JS)}

Job satisfaction is seen to be related to WLB. Further, it is also dependent on Teaching Satisfaction (TS) as discussed initially. The Job Satisfaction Scale used in the present study was adapted from the study of [47]. The elements chosen by [47] to develop the job satisfaction scale were almost identical to those of the popular job descriptive index, which has been found to produce highly-reliable results [48]. The
Job Satisfaction (JS) scale consists of items like nature of the job with respect to teaching and opportunities for doing research. The Teaching Satisfaction (TS) scale was adapted from [55].

\section{Moderating Variables: Demographic Profile}

Several studies in the area [49], [50] have taken gender as moderating variable, whereas in some studies, age is considered as a moderating variable. In several studies [51], marital status was taken as moderating variable. Income has also been taken as a moderating variable in some studies [52], [53].

The moderating variables considered for the present study were gender, nationality, educational status, number of years of experience, and current grade in organization on the lines of [27], [34], [46]. WLB and JS were measured using a 5 -point Likert scale anchored with the end points $1=$ strongly disagree to 5=strongly agree. Reference [55] used a similar scale. In case of measuring JS, a 5-point Likert scale anchored with the end points 1=extremely dissatisfied to $5=$ extremely satisfied was used. These descriptors were chosen to balance or neutralize any tendency to over-report difficult or unacceptable behaviours and conditions faced by the respondents at their workplace [56].

Reference [57] pointed out that researchers should design questionnaire items that capture the specific substantive focus of the component being assessed. Hence, efforts were made to keep the items as simple, specific and objective as possible. Reference [58] found that a long questionnaire tends to have a lower response rate. For this study, the questionnaire length was deliberately kept at two sides of a single page.

As the study was conducted in the Sultanate of Oman where the native language is Arabic, the complete questionnaire, including instructions, scale and questions were translated into Arabic. To avoid discrepancies in translation, back translation method suggested by [59] was used.

\section{1) Pilot testing}

A pilot study was conducted to determine if responses were normally-distributed or skewed. The questionnaire was administered to teaching staff of a higher education institution in Oman. In all, 63 responses were generated at this stage. Based on the input, minor modifications were incorporated in the questionnaire wording, thus enhancing its content validity. The responses generated during the pilot were also tested using SPSS version 17.0, and it was found that the responses were normally-distributed, thereby, suggesting that the instrument was appropriate for further data collection.

\section{2) Sampling technique}

In order to ensure a rigorous research design, care was exercised that a sound sampling procedure was followed. Sampling units, sampling elements and sampling frames were carefully selected. Both private and public higher education institutions in Oman were included in the study.

The sampling frame was derived from the database of the Directorate General of Private Universities and Colleges of the Ministry of Higher Education (MoHE), Sultanate of 
Oman. For the study, the respondents were teachers in both public and private higher education institutions in Oman. A total of 1769 teachers from private institutions were contacted, and out of the total of 2717 employees in the government institutions, 1500 could be approached owing to a refusal of certain institutions to participate in the survey. Data was collected from the sample organizations primarily through postal mails, e-mails (2000) and personal visits (1269). The mail methodology has also been used by other researchers in this area of study [60].

Reference [61] suggested that an adequate sample size for CFA analysis or Structural Equation Modeling (SEM) is 100-150 participants. Further [62] suggests that the ratio of sample size to free parameters should ideally be 5:1 though a ratio of 10:1 may be appropriate. Since the final number of responses was 625 , the ratio was more than the recommended ratio, thus signaling that the sample size was appropriate to proceed with SEM.

\section{CONCEPtual Model of Research}

Several scholars [6], [7], [44], [46], [63], [64], [65] have shown that WLB affects organization commitment, employee loyalty and job satisfaction. Based on the findings, a research model was conceptualized. Exhibit 1 illustrates the conceptual research model.

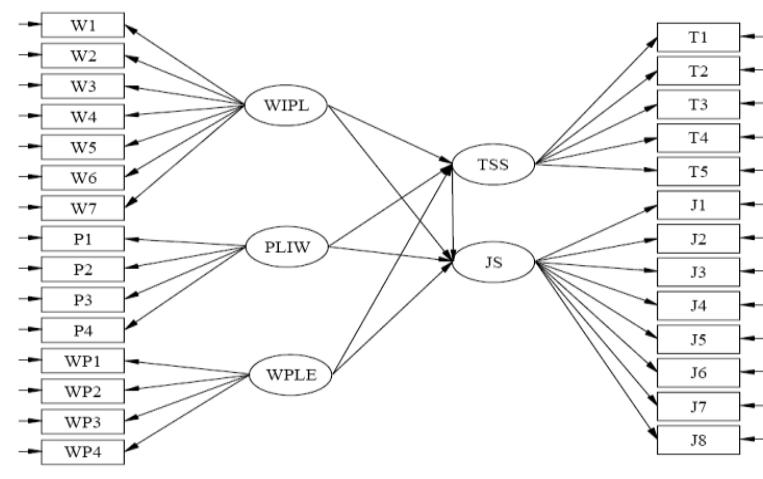

Exhibit 1. Conceptual research model.

\section{A. Research Hypotheses}

Four sets of research hypotheses were considered in light of the research model:

\section{1) Investigating the relationship between work interference with personal life (WIPL), teaching satisfaction (TS) and job satisfaction (JS)}

$\mathrm{H}_{01}$ : WIPL has a negative relationship with TS.

$\mathrm{H}_{02}$ : WIPL has a negative relationship with JS.

2) Investigating the relationship between personal life interference with work (PLIW), teaching satisfaction (TS) and job satisfaction (JS)

$\mathrm{H}_{03}$ : PLIW has a negative relationship with TL.

$\mathrm{H}_{04}$ : PLIW has a negative relationship with JS.

3) Investigating the relationship between work Personal life enhancement (WPLE), teaching satisfaction (TS) and job satisfaction (JS)

$\mathrm{H}_{05}$ : WPLE has a positive relationship with TS.
$\mathrm{H}_{06}$ : WPLE has a positive relationship with JS.

4) Investigating the relationship between teaching satisfaction (TS) and job satisfaction (JS)

$\mathrm{H}_{07}$ : Teaching satisfaction (TS) has a positive relationship with JS.

\section{B. Analysis}

Descriptive statistics of the responses were generated through SPSS 17.0. After initial estimation of response rate Confirmatory Factor Analysis (CFA) was carried out using Structural Equation Modeling (SEM) capabilities of LISREL 8.50. Indicator and scale reliability were assessed. Convergent and discriminant validity was ascertained. The relationship between dependent and independent variables was assessed using Maximum Likelihood Estimation (MLE) method in LISREL.

\section{Response Rate and Item Completion Rate}

Out of the 3269 respondents who were contacted through e-mails, postal mails and personal contact, responses were received from 625 respondents. The completed survey instruments totaled around 19.11 per cent response rate. The item completion is another important measure of effectiveness of the survey [66], [67]. Out of the 625 responses initially received, four questionnaires had missing data, hence the item completion rate was 99.0 per cent, suggesting an exceptionally high survey effectiveness.

\section{Assessing Scale Unidimensionality}

Scale unidimensionality was checked using Confirmatory Factor Analysis (CFA). For many researchers, CFA is a more rigorous test of assessing the measurement model when using SEM [68]. Thus, it was decided to perform CFA as a test of scale unidimensionality, reliability and validity.

A goodness of fit index (GFI) of 0.90 or close suggests that evidence for unidimensionality exists. Additionally, Adjusted Goodness of Fit Index (AGFI) 'greater than 0.9' is acceptable [69]. Reference [70] recommend that Normed Fit Index (NFI), Non-Normed Fit Index (NNFI) and the Comparative Fit Index (CFI) should be studied to estimate the accuracy of the different models. Another aspect of evaluating the measurement model is to examine the direction (positive), magnitude (standard loadings of 0.70 or even 0.50 is acceptable) and statistical significance $(t>1.96)$ of the parameter estimates between indicators and latent variables [70]. When the measurement model was estimated using CFA the scales viz. WIPL, PLIW, WPLE and TS, the fit indices were found to be more than the minimum accepted values. A summary of items in each scale with their GFI values are given in Table I along with loading value range.

\begin{tabular}{|c|c|c|}
\multicolumn{4}{|c|}{ TABLE I: GFI VALUES FOR ALL SCALES } \\
\hline Scale & $\begin{array}{c}\text { Number of Items with } \\
\text { GFI values }\end{array}$ & $\begin{array}{c}\text { Loading Value } \\
\text { Range }\end{array}$ \\
\hline WIPL & 7 Items (GFI=0.90) & $0.64-0.84$ \\
\hline PLIW & 4 Items (GFI=0.95) & $0.70-0.90$ \\
\hline WPLE & 4 Items (GFI=0.93) & $0.60-0.77$ \\
\hline TS & 5 Items (GFI=0.92) & $0.59-0.86$ \\
\hline JS & 8 Items (GFI=0.90) & $0.46-0.75$ \\
\hline
\end{tabular}




\section{E. Assessment of Reliability}

After establishing the unidimensionality of the scales, the researchers tested the statistical reliability of the scales before proceeding with the validation analysis. Two types of reliability estimates were calculated, namely, (1) Indicator reliability and (2) Scale reliability. The indicator reliability of the five scales, namely, WIPL, PLIW, WPLE, TS and JS, used in this study were high or close to the desired values. Scale reliability was measured using Cronbach's alpha as well as SEM-based construct-reliability and variance-extracted measures as suggested by [70]. All values were found to be acceptable. Reliability values are shown in Table II.

TABLE II: RELIABILITY ESTIMATES

\begin{tabular}{|c|c|c|c|c|}
\hline Scale & $\begin{array}{c}\text { Indicator } \\
\text { Reliability } \\
\text { range }\end{array}$ & $\begin{array}{c}\text { Cronbach's } \\
\text { alpha }\end{array}$ & $\begin{array}{c}\text { Construct } \\
\text { Reliability } \\
\text { (CR) }\end{array}$ & $\begin{array}{c}\text { Variance } \\
\text { Extracted } \\
\text { (VE) }\end{array}$ \\
\hline WIPL & $0.4-0.7$ & 0.9 & 0.9 & 0.6 \\
\hline PLIW & $0.5-0.8$ & 0.9 & 0.9 & 0.6 \\
\hline WPLE & $0.4-0.6$ & 0.8 & 0.8 & 0.5 \\
\hline TS & $0.4-0.7$ & 0.8 & 0.8 & 0.5 \\
\hline JS & $0.3-0.6$ & 0.8 & 0.8 & 0.4 \\
\hline
\end{tabular}

\section{F. Convergent and Discriminant Validity}

Reference [71] explained that internal consistency is a type of convergent validity that attempts to assure that there is at least moderate correlation among the indicators. For this study, all the scales had loadings of more than 0.5 which indicates convergent validity. The convergent validity of the five scales was also checked through the Bentler-Bonett Normed Fit Index (NFI). A value of 0.90 and above demonstrates strong convergent validity [72]. The NFI and NNFI coefficient for all the constructs was greater than 0.90 , indicating high convergent validity. The values are depicted in Table III.

TABLE III: NFI AND NNFI VALUES OF SCALES
\begin{tabular}{|c|c|c|}
\hline Scale & NFI & NNFI \\
\hline WIPL & 0.94 & 0.91 \\
\hline PLIW & 0.96 & 0.90 \\
\hline WPLE & 0.91 & 0.80 \\
\hline TS & 0.91 & 0.90 \\
\hline JS & 0.90 & 0.90 \\
\hline
\end{tabular}

For the study, the difference between the alpha value for each of the five constructs and the average correlation of each construct with other constructs was fairly large. This provides evidence of discriminant validity for the five scales. Table IV provides evidence for discriminant validity for all the five scales used for the present study.

\begin{tabular}{|c|c|c|c|c|c|c|c|c|}
\hline \multirow{2}{*}{ Scale } & \multicolumn{5}{|c|}{ Correlations } & \multirow{2}{*}{$\begin{array}{l}\text { Average of } \\
\text { Correlations }\end{array}$} & \multirow{2}{*}{$\begin{array}{l}\text { Alpha } \\
\text { Values }\end{array}$} & \multirow[t]{2}{*}{$\begin{array}{c}\text { Existence of } \\
\text { DV }\end{array}$} \\
\hline & WIPL & PLIW & WPLE & TS & JS & & & \\
\hline WIPL & 1.0 & 0.57 & 0.21 & 0.45 & 0.45 & 0.4 & 0.9 & $\uparrow$ \\
\hline PLIW & - & 1.00 & 0.12 & 0.41 & 0.43 & 0.4 & 0.9 & $\uparrow$ \\
\hline WPLE & - & - & 1.00 & 0.29 & 0.22 & 0.2 & 0.8 & $\uparrow$ \\
\hline TS & $\begin{array}{ll}- & \text { r }\end{array}$ & $\begin{array}{ll}- & - \\
-1\end{array}$ & $\begin{array}{lll}- & - \\
\end{array}$ & 1.00 & 0.68 & 0.5 & 0.8 & $\uparrow$ \\
\hline JS & $\begin{array}{l}- \\
-\end{array}$ & - & - & - & 1.00 & 0.5 & 0.8 & $\uparrow$ \\
\hline
\end{tabular}

The GFI values of all the study scales presented in Table I are significant and fall in line with the recommended values. The high values are an evidence of both convergent and discriminant validity since strong GFI is characteristic of convergence within a construct as well indicative of one construct being different from others.

\section{Structural MOdel ASSESSMENT}

For the present study the structural model fit was assessed to examine the hypothesized relationships between WIPL, PLIW and WPLE dimensions (independent variables) and TS and JS (dependent variable). Five moderating variables were considered, namely, gender, nationality, educational status, years of experience and current grade in organization. To control the effect of moderating variables in the structural model analysis, all the moderating variables were first included in a correlation matrix along with the other study variables ( WIPL, PLIW, WPLE, TS and JS), in line with a method suggested by [54]. None of the moderating variables were found to be significantly correlated with the study variables. All correlation values indicated a weak correlation. Thus, it was concluded that the hypothesized moderating variables did not have a significant influence on the relationships and, hence, they were not incorporated in the final structural model.

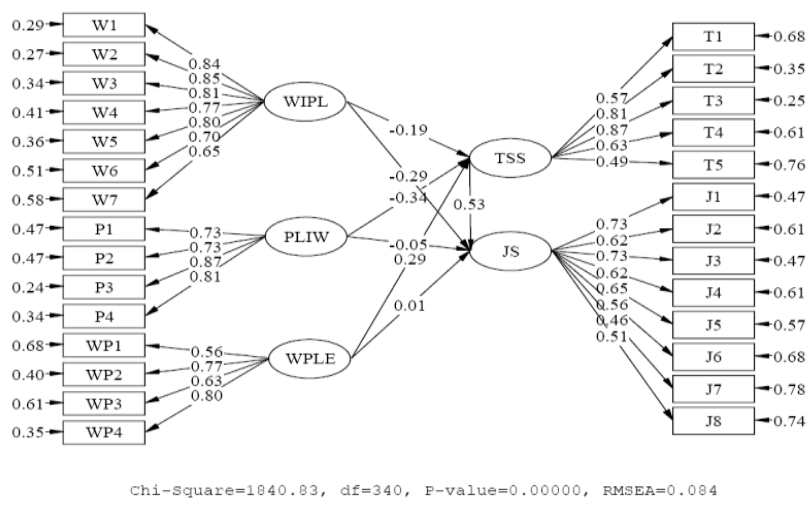

Exhibit 2. Structural model. 
The standardized path coefficients of the structural model as estimated by LISREL 8.50 were used to assess the magnitude and direction of relationships and test the study hypotheses. The structurally-assessed model is depicted in Exhibit 2.

WIPL had a negative relationship with teaching satisfaction as indicated by the structural path coefficient $(\beta=-0.19)$.

WIPL had a negative relationship with job satisfaction as indicated by the structural path coefficient $(\beta=-0.29)$.

PLIW had a negative relationship with teaching satisfaction as indicated by the structural path coefficient $(\beta=-0.34)$.

PLIW also had a negative relationship with job satisfaction as indicated by the structural path coefficient $(\beta=-0.05)$.

WPLE had a positive relationship with teaching satisfaction as indicated by the structural path coefficient $(\beta=0.29)$.

As hypothesized, WPLE had a positive relationship with job satisfaction too as indicated by the structural path coefficient $(\beta=0.01)$. Teaching satisfaction and job satisfaction have a positive relationship as is evident from the structural path coefficient $(\beta=0.53)$. Thus, it can be seen that all the study hypotheses were accepted. The fit indices are given in Table V. All values are acceptable indicating a high model fit.

TABLE V: CRITERION VALIDITY SEM FIT INDICES

\begin{tabular}{|l|c|}
\hline \multicolumn{1}{|c|}{ FIT INDICATORS } & Value \\
\hline Goodness of Fit Index (GFI) & 0.8 \\
\hline Adjusted Goodness of Fit Index (AGFI) & 0.8 \\
\hline Normed Fit Index (NFI) & 0.9 \\
\hline Non-Normed Fit Index (NNFI) & 0.9 \\
\hline Comparative Fit Index (CFI) & 0.9 \\
\hline $\begin{array}{l}\text { Root Mean Square Error of Approximation } \\
\text { (RMSEA) }\end{array}$ & 0.08 \\
\hline
\end{tabular}

It is interesting to note that criterion-related validity is a measure of how well scales representing the various independent (predictor) variables are related to measures of dependent variable (criteria) [73]. The relations between independent and dependent variables in this study, as assessed by SEM have been discussed. This is indicative of high criterion validity.

\section{CONCLUSIONS}

The values of the structural equation model indicated that WIPL and PLIW had a negative relationship with teaching satisfaction and job satisfaction, whereas WPLE had a positive relationship with both teaching satisfaction and job satisfaction. Further, teaching satisfaction also had a positive relationship with job satisfaction. Thus, it was evident that the hypothesized model holds in the context of the present study as all hypotheses were accepted.

Thus, the findings of the study corroborate with previous research evidences [74]. The findings from the study support the path-breaking research by [75] who identify the 'Cognitive Intrusion of Work', which is interference of work-related thoughts and worrying aspects during non-work settings and non-work timings. Reference [75] also reports that cognitive intrusion of work reduces job satisfaction. This was hypothesized in the [46] scale too used by the researchers.

Thus, we can safely conclude that work and personal life need to be integrated in a smooth manner and should not be left to impact on each other in a negative way. This balance or imbalance is likely to affect the overall performance of the teachers as well as the overall performance of the organization [76].

In organizations where employees perceive that work-life balance policies like flexibility, family-friendly benefits, work-life programmes and initiatives exist, it shows that employers are interested in the benefit and well-being of their employees. As a consequence, employees' job satisfaction is enhanced leading to heightened levels of commitment and loyalty to the organizational objectives and mission [27], [77]-[81].

An important contribution of this study is that it adds to the base of information and knowledge in this domain, by exploring the relatively-uncharted context of Oman. It is also noteworthy that it is a pioneering work in Oman, and has significant implications for researchers as well as policy makers in higher education institutions in the Sultanate of Oman. This study validates the relationship between work-life balance, teaching satisfaction and job satisfaction in the context of higher education institutions in the Sultanate of Oman. It can be replicated in other contexts and cultural settings by future researchers.

\section{ACKNOWLEDGMENT}

The authors acknowledge the respondents and colleagues who supported us to complete this research.

\section{REFERENCES}

[1] S. Kar and K. C. Misra, "Nexus between work life balance practices and employee retention-the mediating effect of a supportive culture," Asian Social Science, vol. 9, no. 11, pp. 63-69, Sep. 2013.

[2] U. Byrne, "Work-life balance: Why are we talking about it at all?" Business Information Review, vol. 22, no. 1, pp. 53-59, Mar. 2005.

[3] D. Clutterbuck, Managing Work-Life Balance: A guide for HR in Achieving Organisational and Individual Change, London: UK Chartered Institute of Personnel and Development, Sep. 2003.

[4] N. Bonney, "Overworked Britons? Part-time work and work-life balance," Work Employment Society, vol. 19, no. 2, pp. 391-401, Jun. 2005 .

[5] J. T. Bond, E. Galinsky, and J. E. Swanberg, The National Study of the Changing Workforce, Families and Work Institute, New York, NY 10001: 330 Seventh Avenue, 1997.

[6] R. J. Burke and E. R. Greenglass, "Work-life congruence and work-life concerns among nursing staff," Canadian Journal of Nursing Leadership, vol. 12, no. 2, pp. 21-29, Dec. 1996.

[7] E. E. Kossek and C. Ozeki, "Work-family conflict, policies, and the job-life satisfaction relationship: A review and directions for organizational behavior-human resources research," Journal of Applied Psychology, vol. 83, no. 2, pp. 139-149, Apr. 1998.

[8] S. E. Anderson, B. S. Coffey, and R. T. Byerly, "Formal organizational initiatives and informal workplace practices: Links to work-life conflict and job-related outcomes," Journal of Management, vol. 28, no. 6, pp. 787-810, Dec. 2002.

[9] U. Kinnunen and S. Mauno, "Antecedents and outcomes of work-family conflict among employed women and men in Finland," Human Relations, vol. 51, pp. 157-77, Feb. 1998. 
[10] K. E. MacEwen and J. Barling, "Daily consequences of work interference with family and family interference with work," International Journal of Work, vol. 8, pp. 244-254, Jul. 1994.

[11] M. R. Frone, M. Russell, and M. L. Barnes, "Relationship of work-family conflict, gender and alcohol expectancies to alcohol use/abuse," Journal of Organisational Behaviour, vol. 14, pp. 545-58, Nov. 1996.

[12] W. R. Nord, S. Fox, A. Phoenix, and K. Viano, "Real-world reactions to work-life balance programs: lessons for effective implementation," Organisational Dynamics, vol. 30, no. 3, pp. 223-38, May 2002.

[13] G. Johansson, "Work-life balance: The case of Sweden in the 1990s," Social Science Information, vol. 41, pp. 303-317, Jun. 2002.

[14] D. S. Carlson, M. K. Kacmar, and L. J. Williams, "Construction and initial validation of a multidimensional measure of work- family conflict," Journal of Vocational Behavior, vol. 56, pp. 249-276, Apr. 2000.

[15] J. W. Budd and K. Mumford, "Family-friendly work practices in Britain: availability and perceived accessibility," IZA Discussion Paper no. 1662, Feb. 2005

[16] S. Tipping, J. Chanfreau, J. Perry, and C. Tait, "The fourth work life balance employees survey," Employees Relations Research Series, vol. 122, Jul. 2012.

[17] N. Bloom, T. Kretschmer, and J. V. Reenan, "Work-life balance, management practices and productivity," in International Differences in the Business Practices and Productivity of Firms, R. B. Freeman, and K. L. Shaw, Chicago: The University of Chicago Press, 2009, ch. 1 , pp. $15-54$.

[18] T. A. Scandura and M. J. Lankau, "Relationships of gender, family responsibility and flexible work hours to organizational commitmen and job satisfaction," Journal of Organizational Behavior, vol. 18, no. 4, pp. 377-391, Jul. 1997.

[19] P. Berg, A. L. Kalleberg, and E. Appelbaum, "Balancing work and family: The role of high-commitment environments," Industrial. Relations, vol. 42, no. 2, pp. 168-188, Mar. 2003.

[20] S. L. Grover and K. J. Crooker, "Who appreciates family-responsive human resource policies: The impact of family-friendly policies on the organizational attachment of parents and non- parents," Personnel Psychology, vol. 48, pp. 271-288, Jun. 1995.

[21] S. Khan and K. Agha, "Dynamics of the work-life balance at the firm level: Issues and challenges," Journal of Management Policy \& Practice, vol. 14, no. 4, pp. 103-114, Oct. 2013.

[22] T. Beauregard and L. Henry, "Making the link between work-life balance practices and organizational performance," Human Resource Management Review, vol. 19, no. 1, pp. 9-22, Sep. 2009.

[23] S. Fleetwood, "Rethinking work-life balance: Editor'S introduction," The International Journal of Human Resource Management, vol. 18, no. 3, pp. 351-359, Mar. 2007.

[24] L. Diaz-Serrano and J. A. C. Vieira, "Low pay, higher pay and job satisfaction within the European Union: Empirical evidence from fourteen countries," IZA Discussion Paper Series 1558, 2005.

[25] A. R. Arthur, "Work-related stress, the blind men and the elephant," British Journal of Guidance and Counselling, vol. 32, no. 2, pp 157-169, May 2004.

[26] A. Sousa-Poza and A. A. Sousa-Poza, "Well-being at work: A cross-national analysis of the levels and determinants of job satisfaction," Journal of Socio-Economics, vol. 29, no. 6, pp. 517-538, Nov. 2000.

[27] S. Forsyth and A. Polzer-Debruyne, "The organisational pay-offs for perceived work-life balance support," Asia Pacific Journal of Human Resources, vol. 45, no. 1, pp. 113-123, Apr. 2007.

[28] J. Hughes and N. Bozionelos, "Work-life balance as source of job dissatisfaction and withdrawal attitudes: An exploratory study on the views of male workers," Personnel Review, vol. 36, no. 1, pp. 145-154, Jan. 2007.

[29] E. Babakus, D. W. Cravens, M. Johnston, and W. C. Moncrief, "Examining the role of organizational variables in the salesperson job satisfaction model," Journal of Personal Selling and Sales Management, vol. 16, no. 3, pp. 33-46, Jan. 1996.

[30] K. Ward and L. Wolf-Wendel, "Academic motherhood: Managing complex roles in research universities," Review of Higher Education, vol. 27, no. 2, pp. 233-257, Dec. 2004.

[31] W. Erskine and R. Spalter-Roth, "Beyond the fear factor," Change: The Magazine of Higher Learning, vol. 37, no. 6, pp. 18-25, Nov. 2005.

[32] S. H. Lease, "Occupational role stressors, coping, support, and hardiness as predictors of strain in academic faculty: An emphasis on new and female faculty," Research in Higher Education, vol. 40, no. 3, pp. 285-307, Jun. 1999
[33] J. Waltman and L. August, "Culture, climate, and contribution: Career satisfaction among female faculty," Research in Higher Education, vol. 45, no. 2, pp. 177-192, Mar. 2004.

[34] L. S. Hagedorn, "Wage equity and female faculty job-satisfaction: the role of wage differentials in a job satisfaction causal model," Review of Higher Education, vol. 37, no. 5, pp. 230-282, Oct. 1996

[35] K. W. Kuehn and Y. Al-Busaidi, "Citizenship behavior in anon-western context: an examination of the role of satisfaction, commitment and job characteristics on self-reported OCB," International Journal of Commerce and Management, vol. 12, no. 2, pp. 107-125, Feb. 2002.

[36] S. Azeem, "Job Satisfaction and organizational commitment among employees in the sultanate of Oman," Psychology, vol. 1, pp. 295-299, Oct. 2010.

[37] R. K. R. Al-Neimi and I. H. Amzat, "Teachers perception of their job satisfaction and turnover: A case study of some schools in sultanate of Oman," OIDA International Journal of Vocational Behavior, vol. 58 , pp. 414-435, May 2012.

[38] The Vision for Oman's Economy: Oman 2020. [Online]. Available: http://shodhganga.inflibnet.ac.in/bitstream/10603/3836/11/11_chapter \%206.pdf

[39] C. J. Hobson, L. Delunas, and D. Kesik "Compelling evidence of the need for corporate work-life balance initiatives: Results from a national survey of stressful life events," Journal of Employment Counseling, vol. 38, no. 1, pp. 38-44, Mar. 2001.

[40] S. Dex and S. Bond, "Measuring work-life balance and its covariates," Work, Employment and Society, vol. 19, no. 3, pp. 627-637, Sep. 2005

[41] F. Pichler, "Determinants of work-life balance: Shortcomings in the contemporary measurement of WLB in large-scale surveys," Social Indicators Research, vol. 92, pp. 449-469, Jul. 2009.

[42] K. Fisher and M. Layte, "Measuring work-life balance and degrees of sociability: A focus on the value of time use data in the assessment of quality of life. Working Paper of the European Panel Analysis Group 32. 2002.

[43] A. Chang, P. McDonald, and P. Burton, "Methodological choices in work-life balance research 1987 to 2006: A critical review," The International Journal of Human Resource Management, vol. 21, no. 13, pp. 2381-2413, Oct. 2010.

[44] S. A. E. Geurts, T. W. Taris, M. A. J. Kompier, J. S. E. Dikkers, M. L. M. Van Hooff, and U. M. Kinnunen, "Work home interaction from a work psychological perspective: Development and validation of a new questionnaire, the SWING," Work \& Stress, vol. 19, no. 4, pp. 319-339, Oct. 2005.

[45] J. K. Crooker, L. F. Smith, and F. Tabak, "Creating work-life balance: A model of pluralism across life domains," Human Resource Development Review, vol. 1, no. 4, pp. 387-419, Dec. 2002.

[46] J. Hayman, "Psychometric assessment of an instrument designed to measure work life balance," Research and Practice in Human Resource Management, vol. 13, no. 1, pp. 85-91, 2005.

[47] T. Oshagbemi, "Job satisfaction and dissatisfaction in higher education," Education and Training, vol. 39, no. 9, pp. 22. Dec. 1997.

[48] N. Imparato, "Relationship between porters need satisfaction questionnaire and job descriptive index," Journal of Applied Psychology, vol. 56, no. 5, pp. 397-399, Oct. 1972.

[49] J. P. Robinson and G. Godbey, Time for Life: The Surprising Ways Americans Use their Time, State College: The Pennsylvania State University Press, Nov. 1997.

[50] I. Bacik and E. Drew, "Struggling with juggling: Gender and work-life balance in legal profession," Women's studies International Forum, vol. 29, pp. 136-146, May 2006.

[51] Z. Aycan and M. Eskin, "Childcare, spousal, and organizational support in predicting work-family conflict for females and males in dual-earner families with preschool children," Sex Roles, vol. 53, no. 7, pp. 453-471, 2005.

[52] H. Dean, "Tipping the balance: The problematic nature of work-life balance in a low-income neighborhood," Journal of Social Policy, vol. 36, pp.17-29, Oct. 2007.

[53] H. Dean and A. Coulter, "Work-life balance in a low-income neighbourhood," CASE paper 114, London: London School of Economics, Nov. 2006

[54] A. S. Green, E. Rafaeli, N. Bolger, P. E. Shrout, and H. T. Reis, "Paper or plastic? Data equivalence in paper and electronic diaries," Psychological Methods, vol. 11, no. 1, pp. 87-105, Mar. 2006.

[55] C. L. Ho, and W. T. Au, "Teaching satisfaction scale: measuring job satisfaction of teachers," Educational and psychological Measurement vol. 66, pp. 172-185, Feb. 2006. 
[56] K., Fairbrother and J. Warn, "Workplace dimensions, stress and job satisfaction," Journal of Managerial Psychology, vol. 18, no. 1, pp. 8-21, Feb. 2003

[57] J. B. Arthur and T. Boyles, "Validating the human resource system structure: A levels- based strategic HRM approach," Human Resource Management Review, vol. 17, no. 1, pp. 77-92, Mar. 2007.

[58] C. Iglesias and D. Torgerson, "Does length of questionnaire matter? a randomized trial of response rates to a mailed questionnaire," Journal of Health Service, vol. 5, no. 1, pp. 201-219, Oct. 2000.

[59] R. T. Green and P. D. White, "Methodological considerations in cross-national consumer research," Journal of International Business Studies, vol. 7, pp. 81-87, Oct. 1976.

[60] R. J. Burke, "Do managerial men benefit from organizational values supporting work-personal life balance?" Women in Management Review, vol. 15, no. 2, pp. 91, Mar. 2000

[61] L. Ding, W. F. Velicer, and L. L. Harlow, "Effects of estimation methods, number of indicators per factor, and improper solutions on structural equation modeling fit indices," Structural Equation Modeling, vol. 2, no. 2, pp. 119-143, Jan. 1995.

[62] P. M. Bentler and C. Chou "Practical issues in structural modeling," Sociological Methods and Research, vol. 16, pp. 78-117, Aug. 1987.

[63] T. D. Allen, "Family-supportive work environments: The role of organizational perceptions," Journal of Vocational Behavior, vol. 21 , no. 1, pp. 19-43, Jun. 2001

[64] S. C. Eaton, "If you can use them: Flexibility policies, organizational commitment, and perceived performance," Industrial Relations, vol. 42 no. 2, pp. 145-167, Apr. 2003.

[65] S. K. Aityan and T. K. P. Gupta, "Challenges of employee Loyalty in Corporate America," Journal of Business and Economics, vol. 2011 pp.17-33, Nov. 2011.

[66] E. Deutskens, K. deRuyter, and M. Wetzels, "An assessment of measurement invariance between online and mail surveys," Journal of Service Research, vol. 8, no. 4, p. 346-355, 2010.

[67] R. D. Klassen and J. Jacobs, "Experimental comparison of web, electronic and mail survey technologies in operations management," Journal of Operations Management, vol. 19, no. 6, pp. 713-728, Nov. 2001.

[68] G. J. Medsker, L. J. Williams, and P. J. Holahan, “A review of current practices for evaluating causal models in organizational behavior and human resources management research," Journal of Management. vol. 20, no. 2, pp. 439-464, Apr. 1994

[69] K. G. Jöreskog and D. Sörbom, LISREL 8.80 for Windows [Computer Software]. Lincolnwood, IL: Scientific Software International, Inc., 1993.

[70] M. S. Garver and J. T. Mentzer, "Logistics research methods: Employing structural equation modeling to test for construct validity," Journal of Business Logistics, vol. 20, no. 1, pp. 33-57, Jan. 1999.

[71] R. M. Kaplan and D. P. Saccuzzo, Psychological Testing, Principles, Applications, and Issues, $3^{\text {rd }}$ ed. CA: Wardsworth Inc. 1993.

[72] J. Hartwick and H. Barki, "Explaining the role of user participation in Information System Use," Management Science, vol. 40, no. 4, pp. 440-465, Apr. 1994

[73] S. L. Ahire, D. Y. Golhar, and M. A. Waller, "Development and validation of TQM implementation constructs," Decision Sciences, vol. 27, no. 1, pp. 23-56, Mar. 1996.

[74] L. E. Duxbury, C. A. Higgins, and D. Neufeld, "Telework and the balance between work and family: Is telework part of the problem or part of the solution?" in the Virtual Workplace, M. Igbaria and M. Tan, Hershey, PA: Idea Group Publishing, 1998, pp. 218-255.

[75] S. R. Ezzedeen and P. M. Swiercz, "Rethinking Work-life balance: Development and validation of the cognitive intrusion of work scale (CLWS)," in Proc. the 2002 Eastern Academy of Management Meeting, 2002.

[76] D. Guest, "Perspectives on the study of work-life balance," Social Science Information, vol. 41, no. 255, pp. 255-79, Jun. 2002.

[77] S. J. Callan, "Cultural revitalisation: The importance of acknowledging the values of an organization's "golden era" when promoting work-life balance," Qualitative Research in Organisations and Management: An International Journal, vol. 3, no. 1, pp. 78-97, May 2008.

[78] L. Doherty and S. Manfredi, "Action research to develop work-life balance in a UK university," Women in Management Review, vol. 21, no. 3, pp. 241-59, Apr. 2006

[79] M. R. Frone, "Work-family balance," in Handbook of Occupational Health Psychology, J. C. Quick, and L. E. Tetrick, Ed. APA, Washington, DC, pp. 143-162, 2003.

[80] W. Latham, Intergenerational Conflict between Physicians: Bridging the Great Divide, Unpublished manuscript, 2006.
[81] F. A. Muna and N. Mansour, "Balancing work and personal life: The leader as ACROBAT," Journal of Management Development, vol. 28 , no. 2, pp. 121-133, Feb. 2009

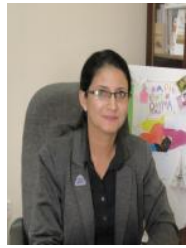

Agha K. was born in India and carries a PhD in HRM from Aligarh Muslim University (AMU), India along with a PG in higher education professional practice (HEPP) from Coventry University, UK. The topic of $\mathrm{PhD}$ was "Relationship between WLB and Job Satisfaction among the teaching staff of Higher Education Institutions in Oman".

She carries 18 years of teaching and dissertation and $\mathrm{PhD}$ supervision experience in Oman and India and currently as Assistan Professor at Skyline University College, Sharjah, UAE. She has worked as Head of PG Department at Middle East College, Oman and Visiting Professor at Sultan Qaboos University, Oman. She has published book chapters and research papers on WLB. Current research interests are about understanding WLB practices in UAE

Dr. Agha is a fellow at the Higher Education Academy, UK since 2010 and currently heads the teaching effectiveness committee at Skyline University College. She has also headed the Linking MED GULF, Erasmus Mundus Project in Oman with University of Barcelona, Spain during 2011. Dr. Agha is reviewer for international journals including Amity Journal of Management Research, Journal of Teaching and Teacher Education, International Journal of Human Resource Management, International Journal of Exclusive Management Research among others.

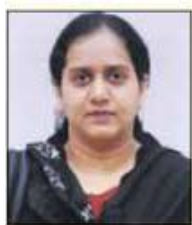

Azmi F. T. was born in India and carries a MBA and $\mathrm{PhD}$ from AMU, Aligarh, India. The topic of $\mathrm{PhD}$ was "Strategic Human Resource Management: An Empirical Study of Selected Public Limited Companies in India". Dr Azmi's major field of study is Strategic HR and organizational behavior.

She is presently senior assistant professor at Faculty of Management Studies \& Research, AMU, India. She has more than 14 years of experience of teaching MBA students and guiding $\mathrm{PhD}$ theses. Her papers have been published in leading international journals including International Journal of Human Resource Management (Routledge), European Business Review (Emerald Publishing), International Journal of Commerce and Management (Emerald Publishing) among others. Her research interests include strategic HRM, work-life balance and organizational learning.

Dr. Azmi is reviewer for international journals including Employee Relations Journal, Personnel Review and Asia-Pacific Journal of Business Administration (by Emerald Publishing) among others. She is life member of various professional associations like National HRD Network, India and Indian Society of Training \& Development. Dr. Azmi's paper titled "Devolution and Organizational Performance: Evidence from India" published in International Journal of Commerce and Management, Vol. 20, No. 3, 2010, Emerald Publishing, was rated among the 'Top 20 downloaded papers' in 2011. Another paper titled "Strategic human resource management and its linkage with HRM effectiveness and organizational performance: Evidence from India", published in The International Journal of Human Resource Management, Vol. 22, Issue 18, 2011, Taylor and Francis Journals has received $\mathbf{2 5 3 0}$ views and more than 10 citations, considered as among the highest for the year. Another research paper titled "Job Related Factors and Organizational Commitment of B-School Teachers in India: The Mediating Effect of Job Satisfaction" was awarded 1 Prize at 2nd International Conference on Exploring Non-Linear Growth through HR Driven Strategies, held at Institute of Management Studies, Noida, India on Oct 12-13, 2012

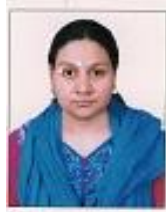

Irfan A. was born in India and has completed schooling from Girls' High School Allahabad in 2003, a BSc (zoology/botany) from University of Allahabad in 2006 , MBA (finance/human resource) and right now pursuing $\mathrm{PhD}$ from Aligarh Muslim University, Aligarh (i.e. August 2012 to present)

She has two years of teaching experience in United Institute of Management Naini, Allahabad prior to her $\mathrm{PhD}$.

Ms. Irfan co-authored a paper titled "Antecedents and Outcomes of Work life balance" published in Book titled "Contemporary Issues in People Management" with ISBN: 978-93-84082-24-6 